ORIGINAL RESEARCH ARTICLE

\title{
A Holistic Approach to Incubator Strategies in the Entrepreneurial Support Ecosystem
}

\author{
Christina Theodoraki* \\ Strategy, Entrepreneurship and Innovation Department, TBS - Toulouse Business School, Toulouse, France
}

\begin{abstract}
This research employs ecosystem and strategic fit theories to understand incubators' relationships with other ecosystem actors by investigating the elaboration of specialization, diversification, and co-opetition strategies. In the entrepreneurial support ecosystem, incubators act as intermediaries, bridging the gap between tenants and their external environment. These strategically led organizations offer a unique perspective for exploring the strategic fit differentiation engine through a holistic approach. A qualitative study reviews 48 semi-structured interviews derived from five case studies of the main incubator types. The results show that incubators differentiate themselves by employing various combinations of individual and collective strategies consisting of individual, organizational, and environmental factors to achieve ecosystem benefits. These findings provide a cross-level understanding of the entrepreneurial support ecosystem for all ecosystem actors and enable the implementation of appropriate generic strategies.
\end{abstract}

Keywords: Ecosystem; Entrepreneurial support; Business incubators; Co-opetition; Strategy

Handling Editor: Saulo Dubart Barbosa; Received: 17 February 20 I7; Accepted: 24 February 2020; Published: I 6 December 2020

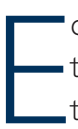
cosystem research is an emerging but underdeveloped theoretical stream that requires additional scientific investigation as it has become the 'latest conceptual fad' (Brown \& Mason, 2017; Jacobides, Cennamo, \& Gawer, 2018; Spigel \& Harrison, 20l8). The current lack of knowledge regarding this issue constitutes a major gap in entrepreneurship research (Thomas \& Autio, 20l4). Indeed, "the ecosystem-based views of entrepreneurship reflect a dynamic and socially complex aspect of action and interaction in the entrepreneurial process" (Goswami, Mitchell, \& Bhagavatula, 20 I 8, p. 119). Reflecting this dynamic and complex view, ecosystem actors struggle to elaborate efficient strategies in the entrepreneurial context (Adner, 2017). Furthermore, this dynamic is related to ecosystem resilience, which enables a better understanding of why some ecosystems thrive (Bernard \& Barbosa, 2016 ; Roundy, Brockman, \& Bradshaw, 2017).

To overcome the complexity of the entrepreneurial ecosystem, early research has mainly focused on its definition and composition (Kœnig, 2012; Spigel, 2017). The entrepreneurial ecosystem is a 'multi-actor' and 'multi-scalar' phenomenon describing "a set of interconnected entrepreneurial actors, institutions and entrepreneurial processes, which formally and informally coalesce to connect, mediate and govern the performance within the local entrepreneurial environment" (Mason \& Brown, 20 I 4, p. 5). Entrepreneurial ecosystem scholars have shifted their focus to explore the strategic dynamics, processes, evolution, and interdependencies of the ecosystem components as they investigate strategies for collaboration and competition (Adner, 2017; Goswami et al., 2018; Kœnig, 201 2; Spigel \& Harrison, 20 18). To assimilate these interactions and their contributions to ecosystem outcomes, clarifying the importance of each actor for the effective functioning of the overall system is fundamental (Morris, Neumeyer, \& Kuratko, 201 5; Stangler \& Bell-Masterson, 20 I5).

Early research demonstrated that incubators and accelerators occupy a central position in the entrepreneurial support ecosystem (Clarysse, Wright, Bruneel, \& Mahajan, 2014; Goswami et al., 20 I8; Klofsten, Lundmark, Wennberg, \& Bank, 2020; Pauwels, Clarysse, Wright, \& Van Hove, 201 6; Rubin, Aas, \& Stead, 20I5; van Weele et al., 2018) by bridging the gap between tenants and their external environment (Bergek \& Norrman, 2008). This 'umbrella' concept is used to describe strategically led organizations that foster a supportive and safe environment for creating and developing new firms during their early life stages (Aernoudt, 2004; Bergek \& Norrman, 2008; Chan \& Lau, 2005; Chandra \& Fealey, 2009).

*Corresponding author: Christina Theodoraki, Email: c.theodoraki@tbs-education.fr 
However, incubators have different goals related to their strategic positioning and uneven quality or efficiency (Aernoudt, 2004; Pena, 2004; Somsuk \& Laosirihongthong, 2014; Tamasy, 2007). The important public funding dedicated to incubators increases concerns regarding their efficiency, evaluation process, and outcomes (Bergek \& Norrman, 2008). Accordingly, incubators are challenged with finding a balance between "opportunity-seeking (entrepreneurship) and advantage-seeking (strategic management) behaviors" (Shankar \& Shepherd, 2019, p. 2). In this ever-changing context characterized by increasing competition between incubators and other ecosystem actors, an emerging research field has focused on incubators' strategic positioning (Baraldi \& Havenvid, 20I6). Nonetheless, this field has primarily focused on individual strategies of specialization, diversification, and/or service-based differentiation (Schwartz \& Hornych, 2008, 2010, 2012; Vanderstraeten \& Matthyssens, 2012) while neglecting collective strategies involving cooperation and competition with other ecosystem actors. Hybrid strategies, such as co-opetition, may provide an important contribution to the sustainability of the entrepreneurial support ecosystem. Co-opetition refers to the combination of two strategic behaviors (cooperation and competition) that are a priori opposed to one another (Akdoğan \& Cingšz, 2012; Bengtsson \& Kock, 1999, 2000; Dagnino, Le Roy, \& Yami, 2007; Robert, Chiambaretto, Mira, \& Le Roy, 2018 ; Yami, Castaldo, Dagnino, \& Roy, 2010 ; Yami, Chappert, \& Mione, 20।5).

By combining these scientific discussions, this study aims to explore incubators' strategic fit (individual and collective strategies) as a driver of differentiation within the entrepreneurial support ecosystem. Similarly, incubators offer a unique perspective for exploring the strategic fit differentiation engine in a holistic manner. Specifically, this research aims to answer the following research question: How do incubators ideally elaborate internal and external strategic fit as a differentiation engine within the entrepreneurial support ecosystem? To address this question, a qualitative methodology was adopted based on five case studies and 48 semi-structured interviews conducted with diverse ecosystem actors.

This paper is structured as follows: (I) a literature review of ecosystem and strategic fit theory adapted to the incubator context, (2) a description of the qualitative methodology used for the data collection and analysis in this study, (3) a presentation of the results discussing the within-case, cross-case, and cross-level findings, and (4) a conclusion summarizing the results, the paper's contributions, and limitations and recommendations for related future research.

\section{A strategic approach to the entrepreneurial support ecosystem}

A successful entrepreneurial support ecosystem requires fostering connections with various heterogeneous actors and networks (Chandra \& Fealey, 2009). However, such heterogeneity increases the complexity of the ecosystem, particularly due to incubator diversity (Theodoraki \& Messeghem, 2017). To better understand the composition of the entrepreneurial support ecosystem, different types of incubators and their services should first be described.

\section{The diversity of incubators and service offerings}

The multitude of incubator types and diversity of service offerings amplify the complexity of the entrepreneurial support ecosystem (Bøllingtoft, 2012; Messeghem, Bakkali, Sammut, \& Swalhi, 20 I 8). The first source of this complexity involves multiple types of incubators differentiated based on their strategic goals, funders, value creation, incubation phases, and target markets (Aernoudt, 2004; Barbero, Casillas, Ramos, \& Guitar, 2012; Carayannis \& von Zedtwitz, 2005; Grimaldi \& Grandi, 2005; McAdam \& Marlow, 2008; Rubin et al., 2015; von Zedtwitz \& Grimaldi, 2006). Furthermore, new hybrid models combining several characteristics, such as geography (urban, suburban, and rural), sponsorship (universities, governments, economic development entities, and corporations), and industry (ICT: Information and Communications Technology, agriculture, and biotechnology), have emerged (Al-Mubaraki \& Busler, 2010 ). Based on the available criteria, incubators can be sorted into the following five categories: economic development incubators, technology incubators, university incubators, social incubators, and private incubators. Some authors refer to other types of incubators, such as virtual incubators (Carayannis \& von Zedtwitz, 2005), bottom-up incubators (Bøllingtoft, 20 I 2), network incubators (Bøllingtoft \& Ulhøi, 2005), and mixed and cooperative incubators (Etzkowitz, de Mello, \& Almeida, 2005). While acknowledging the validity of these types of incubators and different categorization schemes, this study focuses on the five categories delineated earlier. Specifically, economic development incubators are used to enhance regional economic development and employment (von Zedtwitz \& Grimaldi, 2006). Technology incubators attempt to foster the emergence of technology-based firms (Barbero et al., 2012). University incubators facilitate knowledge and technology transfers in addition to providing access to academic networks (Grimaldi \& Grandi, 2005). Social incubators focus on social integration and innovation (Aernoudt, 2004). Private incubators are for-profit organizations and, therefore, are mainly interested in firms that generate short- and/or middle-term profits (Carayannis \& von Zedtwitz, 2005). 
The second source of complexity associated with incubators involves the variety of service offerings. Several authors highlight the need to combine multiple services during the incubation process to satisfy tenants (Aernoudt, 2004; Bergek \& Norrman, 2008; Bøllingtoft, 2012; Bøllingtoft \& Ulhøi, 2005; Carayannis \& von Zedtwitz, 2005; Chan \& Lau, 2005; Clarysse, Wright, Lockett, Van de Velde, \& Vohora, 2005; von Zedtwitz \& Grimaldi, 2006). Carayannis and von Zedtwitz (2005) categorize these services into the following five main categories: access to physical resources, office support, financial resources, entrepreneurial support, and networks. The first type of service relies on hosting and providing physical facilities (offices, furniture, and workout facilities) to tenants. The second type is associated with providing logistical infrastructure and office services (secretarial and reception services, printing, mail delivery, wi-fi, and fax machines). The third type involves access to financial resources, such as angel investors, venture capitalists, public grants, and loans. The fourth type is associated with business coaching regarding management, accounting, financing, and legal and fiscal aspects. The final type provides access to a solid network, which is a key factor in the creation and development of new firms (Bøllingtoft, 2012).

However, an incubator may be unable to offer all services essential for successful incubation, which may consequently lead to the development of cooperative behaviors among ecosystem actors who complement one another. In contrast, the diversity of actors and evolution of the ecosystem drive incubators to develop strategies to obtain competitive advantages and survive, particularly service-based differentiation strategies (Bonel \& Rocco, 2007; Vanderstraeten \& Matthyssens, 2012). This differentiation engine can be further explored through the strategic fit framework.

\section{Incubators' strategic fit in the entrepreneurial support ecosystem}

The notion of strategic fit is the basis of contingency theory (Drazin \& Van de Ven, 1985; Ginsberg, Horwitch, Mahapatra, \& Singh, 20 10; Ginsberg \& Venkatraman, 1985; Kim, Lee, \& Park, 2015; Van de Ven \& Drazin, 1984; Venkatraman \& Camillus, 1984). According to Miller (1992), strategic fit is differentiated as internal or external fit. Internal fit is based on the principle of congruence between a firm's strategy and its organizational characteristics. External fit addresses a firm's external environment, including the alignment between its strategy and environment. Although contingency theory considers alignment between strategy and environment necessary for achieving superior performance, it does not impose 'one best way' to achieve this goal, which is also known as 'equifinality' (Doty, Glick, \& Huber, 1993; Gresov \& Drazin, 1997; Payne, 2006). Similarly, strategic fit enables an analysis of the strategic behaviors of support entities within the entrepreneurial ecosystem (Shankar \& Shepherd, 2019). Moreover, this framework is suitable for exploring generic strategies aiming to link internal and/or external organizational characteristics to identify 'ideal' strategies for each type of incubator (Schwartz \& Hornych, 20 I2; Vanderstraeten \& Matthyssens, 20I2). The evolution of these characteristics may affect an incubator's strategic positioning by leading to 'misfit' or inadequate internal and external fit (Miller, 1992).

Additionally, the literature has focused on incubator efficiency and outcomes over an extended period without demonstrating a shared empirical consensus (Baraldi \& Havenvid, 20 I6; Barbero et al., 20 I 2; Messeghem et al., 20 I 8). Some studies tend to recommend solutions to increase incubators' value creation. Tamasy (2007) argues that incubators should aim to become private entities with no reliance on public funding. Other studies recommend that incubators should develop their overall strategy according to the characteristics and specificities of the environment in which they operate (Bank, Fichter, \& Klofsten, 2017; Baraldi \& Havenvid, 2016 ; McAdam, Miller, \& McAdam, 2016; Schwartz \& Hornych, 2012) while adapting their business models to create and capture value from the ecosystem (Demil, Lecocq, \& Warnier, 2018). This study follows this recommendation to explore strategic incubator practices within the entrepreneurial support ecosystem in a holistic manner; thus, internal fit is explained in terms of the discrete strategies of specialization and diversification, while external fit is discussed in terms of collective strategies, including cooperation/competition (co-opetition) strategies.

\section{Individual strategies: Specialization or diversification?}

The early literature distinguishes between specialized business incubators (SBIs) and diversified business incubators based on their strategic objectives (Schwartz \& Hornych, 2008, 2010, 2012; Vanderstraeten \& Matthyssens, 20I2). The specialization strategy focuses on an industry with the goal of offering services and knowledge in a specific sector and providing specialized equipment that could ultimately improve the perceptions of tenants. SBls select tenants only from a specific industry (or complementary sectors). Nevertheless, although specialization fosters the development of in-depth knowledge regarding an industry segment, it can also lead to a negative work atmosphere, implementation of barriers between tenants, and mistrust regarding sharing information related to the specificity of the sector (Schwartz \& Hornych, 2008, 20 I0). In contrast, the diversification strategy widens the strategic scope in all industry sectors. However, this expansion may lead to competition between an incubator and other ecosystem actors or partners 
who may eventually become co-opetitors (Vanderstraeten \& Matthyssens, 2012).

To reduce competition, some authors recommend concentrating on specialized services and limiting the number of targeted sectors; however, these authors do not empirically show that specialization outperforms diversification as a strategy (Aerts, Matthyssens, \& Vandenbempt, 2007; Grimaldi \& Grandi, 2005; Klofsten et al., 2020; Schwartz \& Hornych, 2008, 2010 ). According to Payne, Kennedy, and Davis (2009), the specialization strategy improves the performance of firms operating in a competitive environment characterized by resource availability and intense interfirm rivalry. Specialization strategy defenders contend that this type of strategy increases incubators' perceived service value among tenants (Schwartz \& Hornych, 2008). Additionally, specialized services focusing on an industry or technology (e.g., media-related services, specialized infrastructure, advanced equipment, or sector-specific knowledge and advice) cannot be easily replicated by other ecosystem actors (Schwartz \& Hornych, 2008). Thus, the specialization strategy decreases competition among ecosystem actors.

Defenders of mixed approaches argue that the coexistence of diversified and specialized actors within an ecosystem is a key factor enabling value creation and collective benefits and/ or performance (Demil et al., 2018; Jacobides et al., 2018; Kapoor, 2013). However, the diversification strategy can also result in a competitive advantage. Thus, diversified incubators may help generate a competitive advantage by providing operational services and engaging in specific studies focusing on marketing and internationalization for tenants in a wide variety of industry sectors (Vanderstraeten \& Matthyssens, 2012). Although the incubator selects the internal strategic positioning of specialization or diversification, it should develop a parallel co-opetition strategy with other ecosystem actors (Baraldi \& Havenvid, 2016). Co-opetitive behaviors among ecosystem actors are more beneficial than applying the cooperation or competition strategy separately because the benefits of both strategies can be reaped simultaneously (Bengtsson \& Kock, 1999; Ritala, Hallikas, \& Sissonen, 2008).

\section{Collective strategies: Co-opetition in the entrepreneurial support ecosystem}

The co-opetition strategy is present in all industries but emerges more regularly in complex and dynamic environments and service-based industries (Bengtsson, Eriksson, \& Wincent, 2010; Carayannis \& Alexander, 1999). In these environments, knowledge acquisition is important for gaining competitive advantages (Robert et al., 2018). Furthermore, the heterogeneity of unique resources and resource munificence can lead to co-opetitive behaviors (Bengtsson \& Kock, 2000; Carayannis \& Alexander, 1999; Huang \& Chu, 2015; Padula \&
Dagnino, 2007). Co-opetition is defined as a complex phenomenon, involving both horizontal and vertical relationships with heterogeneous actors (Chiambaretto \& Dumez, 2016), thus forming a system of interactions based on partially congruent interests and objectives (Dagnino et al., 2007). Within the entrepreneurial support ecosystem, two complementary definitions can be identified. First, incubators may foster collaborative ties with different types of actors, such as policy makers (funders), tenants (users), and other incubators (competitors) (Baraldi \& Havenvid, 2016; Bengtsson \& Johansson, 2014; Brandenburger \& Nalebuff, 1995). Second, incubators may develop activity-based co-opetition, in which they compete for access to public funding while cooperating for access to the skills of other ecosystem actors (Baraldi \& Havenvid, 2016; Bengtsson \& Kock, 2000; Carayannis \& Alexander, 1999; Lair, 2013) (see Figure I).

Finally, the entrepreneurial support ecosystem is a dynamic and highly complex environment, in which a large volume of information and knowledge must be mastered (Carayannis \& Alexander, 1999). Incubators join networks, create synergies, and participate in resource transfers to support new firms. However, the high level of heterogeneity cannot sustain synergy without complementarity (Huang \& Chu, 2015; Thomas \& Autio, 20|4), and this complementarity is based not only on the functional characteristics of each actor but also on their obligations to other ecosystem actors. In addition, interactor complementarity and interdependence are driven by competitive and cooperative dynamics (Bengtsson et al., 20 I 0; Bonel, Pellizzari, \& Rocco, 2008; Bonel \& Rocco, 2007). Thus, complementarity is related to a cumulative dimension of the value added by each actor (Jacobides et al., 2018; Thomas \& Autio, 2014) and is enhanced by reducing duplication in the core capabilities of the ecosystem actors. Accordingly, this framework leads to the following fundamental question: How do incubators ideally elaborate internal (specialization and diversification) and external (cooperation and competition) strategic fit as an engine of differentiation within the entrepreneurial support ecosystem?

\section{Methods}

\section{Research settings}

This study is based on an interpretative, systematic, inductive qualitative research protocol designed as a multiple-case study, enabling a comparative analysis of the data and reinforcing the process of generalizing results (Eisenhardt \& Graebner, 2007; Gioia, Corley, \& Hamilton, 20।3; Yin, 20 I8). This method is suitable for studying phenomena that have been underexplored in the previous literature (Bansal \& Corley, 20 12; Chetty, Partanen, Rasmussen, \& Servais, 2014; Goswami et al., 2018). This study 


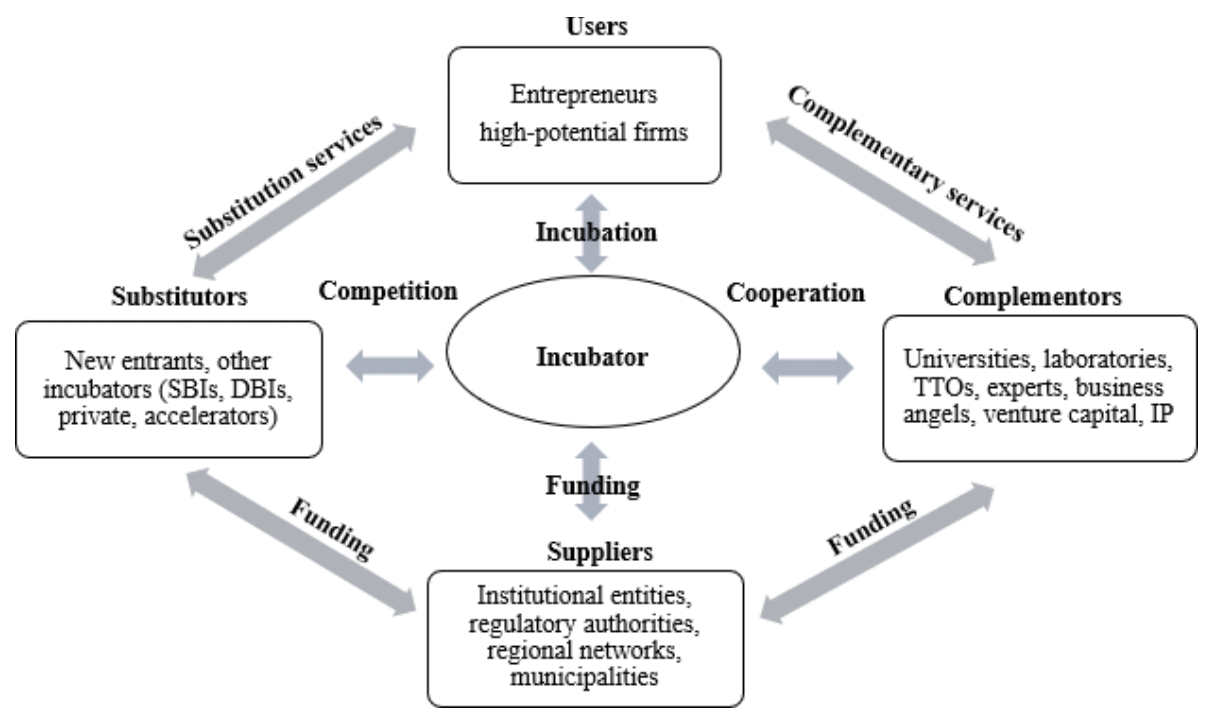

Figure I. Entrepreneurial support ecosystem (adapted from Brandenburger and Nalebuff, 1995)

was conducted in the south of France, which is characterized as a dynamic regional entrepreneurial ecosystem that contains all elements necessary to explore this framework. Cohen (2006) explains that an entrepreneurial ecosystem should contain several categories of entrepreneurial actors (incubators, support experts, research, and funding entities) surrounded by an entrepreneurial culture (based on success stories and talent pools).

Moreover, this study relies on an ecosystem approach based on semi-structured interviews. The ecosystem approach is suitable for (I) conceptualizing the relationships among ecosystem actors, (2) interpreting the complexities in these relationships that can evolve over time, and (3) examining these strategic relationships using systemic logic (Ben Letaifa \& Rabeau, 2013). This approach differs from linear approaches, which are generally not suitable for an ecosystem reading. By employing this methodology, this study aims to cover multiple actors in the entrepreneurial support ecosystem and cross data to increase the reliability of the research (Chetty et al., 20 I4; Minà, Dagnino, \& Ben Letaifa, 20 I5). Additionally, incubators play a key intermediary role in the regional entrepreneurial ecosystem and allow the application of a multiple-level construct in which incubators act at the meso level (intermediaries), tenants are situated at the microlevel, and the regional entrepreneurial ecosystem represents the macro level (Goswami et al., 2018). Thus, this study focused on the interfirm level (i.e., incubators are the research object) to achieve a better understanding of the collective strategies within the entrepreneurial ecosystem (Gnyawali, Madhavan, He, \& Bengtsson, 2016; Mariani, 2016).

\section{Data collection}

The data collection is based on incubators' typologies based on the literature review. Five case studies were selected based on their purpose, task, competitive focus, incubation time, and services, as shown in Table I.

The purposive, theoretical sampling of different groups of actors provided an optimal description of the entrepreneurial support ecosystem. Additionally, snowball sampling was performed to reach theoretical saturation (Aguinis \& Solarino, 2019). In total, I 6 incubator managers, I I incubator staff members, 6 tenants, 3 institutional officials, 3 network coordinators, 4 funders, and 5 research entities were interviewed. This methodological approach distinguishes two levels of analysis, including the incubator level (core actors) and the ecosystem level (peripheral actors). According to Ben Letaifa (20।3), core actors are actors closely linked to the heart of a business, such as staff, users, and suppliers. Furthermore, peripheral actors may be involved in the entrepreneurial support ecosystem and affect its structure and evolution.

The replication design enabled the accumulation of knowledge regarding each case through multiple inter-site experiments involving 23 different incubators. This approach allows several experiments to be conducted within each case and increases the generalizability of the results (Yin, 2018). The research design is based on 48 semi-structured interviews (36 core actor interviewees and 12 peripheral actor interviewees). The interviews include a total of approximately $66 \mathrm{~h}$ of audio recordings and were conducted between June 2013 and November 2014. The interviews were conducted face to face 
Table I. Sample characteristics

\begin{tabular}{|c|c|c|c|c|c|}
\hline & $\begin{array}{l}\text { Case A: economic } \\
\text { development incubators }\end{array}$ & $\begin{array}{l}\text { Case B: technology } \\
\text { incubators }\end{array}$ & $\begin{array}{l}\text { Case C: university } \\
\text { incubators }\end{array}$ & $\begin{array}{l}\text { Case D: social } \\
\text { incubators }\end{array}$ & $\begin{array}{l}\text { Case E: private } \\
\text { incubators }\end{array}$ \\
\hline Purpose & Not-for-profit & Not-for-profit & Not-for-profit & Not-for-profit & For-profit \\
\hline Task & $\begin{array}{l}\text { Develop the regional } \\
\text { economy }\end{array}$ & $\begin{array}{l}\text { Create and sustain } \\
\text { high-potential tech } \\
\text { firms }\end{array}$ & $\begin{array}{l}\text { Promote academic } \\
\text { entrepreneurship and } \\
\text { develop and commercial- } \\
\text { ize academic research }\end{array}$ & $\begin{array}{l}\text { Create and maintain } \\
\text { high-potential } \\
\text { social-focused firms }\end{array}$ & $\begin{array}{l}\text { Accelerate firm creation } \\
\text { and development }\end{array}$ \\
\hline $\begin{array}{l}\text { Competitive } \\
\text { focus }\end{array}$ & $\begin{array}{l}\text { Specific location (local or } \\
\text { regional) }\end{array}$ & $\begin{array}{l}\text { Industry or sector } \\
\text { (Internet and ICT) }\end{array}$ & Academic spin-offs & $\begin{array}{l}\text { Cooperatives and } \\
\text { start-ups from the } \\
\text { social solidarity } \\
\text { economy }\end{array}$ & $\begin{array}{l}\text { Start-ups mainly related } \\
\text { to ICT }\end{array}$ \\
\hline Incubation phase & Before and after creation & Mainly after creation & Mainly before creation & Mainly before creation & Before and after creation \\
\hline Incubation time & Medium/long & Medium/long & Short/medium & Medium/long & Short \\
\hline Range of services & Mixed services & $\begin{array}{l}\text { Technology-based } \\
\text { services }\end{array}$ & $\begin{array}{l}\text { Research-oriented } \\
\text { services }\end{array}$ & Mixed services & Mixed services \\
\hline
\end{tabular}

using an interview guide covering the following three topics: (I) the incubator's organizational characteristics (internal fit, service offering, specificities, and differentiation), (2) the ecosystem's characteristics (external fit, interaction with other actors, and types of relationships), and (3) the ecosystem's benefits (value creation, efficiency, and the impact of ecosystem relationships on performance).

To guarantee the validity and reliability of the findings, multiple sources of evidence were proactively collected as a means of triangulating information (Gibbert, Ruigrok, \& Wicki, 2008). The data include both primary data (from semi-structured interviews with various ecosystem actors) and secondary archival data (from site visits, websites, brochures, annual reports, press releases, and e-mails) (see Table 2). The researcher first crafted and validated the interview guide with other researchers and experts while striving to maintain a neutral point of view while conducting the interviews. Interobserver reliability was assessed across the study's multiple respondents. The researcher also carried out two pilot interviews with an incubator manager and an incubator staff member to confirm the appeal of the research question and ensure that the questions in the interview guide were clear to the informants. Their feedback confirmed the importance of the research question, prompted minor changes to the interview guide, and prepared the researcher to conduct the interviews.

\section{Data analysis}

Regarding data processing, a content analysis is frequently used to examine the differences among strategic groups in the field of strategic management (Short, Payne, \& Ketchen, 2008). More precisely, a thematic analysis using Nvivo I 2 software (QSR International) was performed in three stages
(Bazeley \& Jackson, 2013). First, II4 codes were created using an explorative open coding that allowed the identification of emerging ideas regarding the representative quotes. These first-order concepts show the informants' voice and are formulated with similar terms in small phrases or labels. Second, some codes were deleted, some codes were created, and other codes were simply grouped. Sets of gathered quotes from each group were created using the Matrix Query Wizard for cross tabulations of the content encoding. This axial coding enabled comparisons across the different responses given by the informants and related the concepts to each other to establish themes. The second-order themes show the researcher's voice and interpretation of the informants' terms. Third, comparisons of the existing literature and coded data revealed the aggregate dimensions, as shown in Figure 2. During this stage, the relationships between the first-order concepts and second-order themes were examined to reveal the more general dimensions of the modeling process. This final stage enabled the transformation of the static data structure into a dynamic understanding of the interrelationships among the concepts. Furthermore, the Gioia methodology was used to achieve qualitative rigor in the analysis and interpretation of the results (Gioia et al., 2013). To ensure the quality of the encoding process, the data were coded twice with an interval of a few months to ensure the objectivity of the researcher. Moreover, to minimize bias, the researcher requested the opinions of experts not involved in the study regarding the data analysis process, coding themes, and result interpretation. These regular meetings provided an outsider's view of the research design and findings (Corley \& Gioia, 2004). Finally, this modeling was presented to key informants in the regional entrepreneurial ecosystem to achieve rigor, increase its trustworthiness, and ensure construct validity (Gibbert et al., 2008). 
Table 2. Description of the collected qualitative data

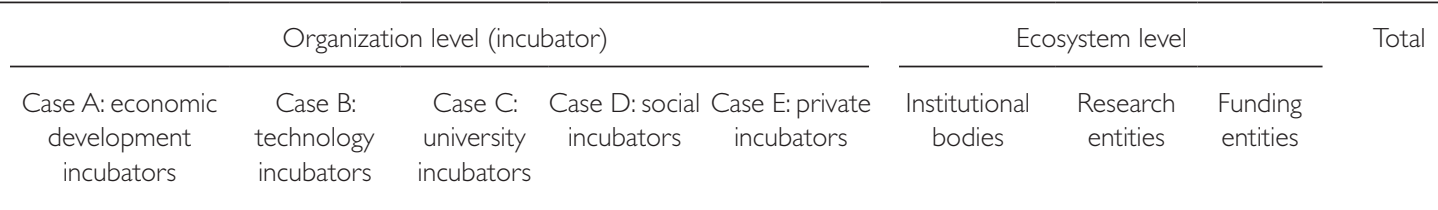

\begin{tabular}{|c|c|c|c|c|c|c|c|c|c|}
\hline $\begin{array}{l}\text { Number of } \\
\text { incubators }\end{array}$ & 10 & 3 & 3 & 3 & 4 & - & - & - & 23 \\
\hline $\begin{array}{l}\text { Number of } \\
\text { interviewed actors }\end{array}$ & 13 & 4 & 9 & 6 & 4 & 3 & 5 & 4 & 48 \\
\hline $\begin{array}{l}\text { Duration of } \\
\text { interviews } \\
(\mathrm{HH}: \mathrm{MM})\end{array}$ & $|6: 4|$ & 05:33 & | 3:07 & $08: 38$ & $06: 58$ & $04: 14$ & $05: 21$ & $05: 24$ & $65: 56$ \\
\hline $\begin{array}{l}\text { Total number of } \\
\text { transcribed pages }\end{array}$ & 325 & 108 & 204 & 117 & 80 & 84 & 82 & | | | & I, I I | pages \\
\hline $\begin{array}{l}\text { Total number of } \\
\text { verbatim quotes } \\
\text { coded }\end{array}$ & 1,440 & 460 & 1,000 & 268 & 667 & 480 & 368 & 225 & $\begin{array}{l}4,908 \\
\text { verbatim } \\
\text { quotes } \\
\text { coded }\end{array}$ \\
\hline $\begin{array}{l}\text { Total amount of } \\
\text { secondary data }\end{array}$ & $\begin{array}{l}\text { I } 39 \text { pages }+ \\
04: 58 \text { of } \\
\text { various } \\
\text { meetings }\end{array}$ & $\begin{array}{l}43 \text { pages }+ \\
03: 49 \text { of } \\
\text { various } \\
\text { meetings }\end{array}$ & $\begin{array}{l}314 \text { pages } \\
+00: 59 \text { of } \\
\text { various } \\
\text { meetings }\end{array}$ & $\begin{array}{l}176 \text { pages } \\
+02: 23 \text { of } \\
\text { various } \\
\text { meetings }\end{array}$ & - & - & - & - & $\begin{array}{l}672 \text { pages } \\
+12: 09 \\
\text { of group } \\
\text { meetings }\end{array}$ \\
\hline
\end{tabular}

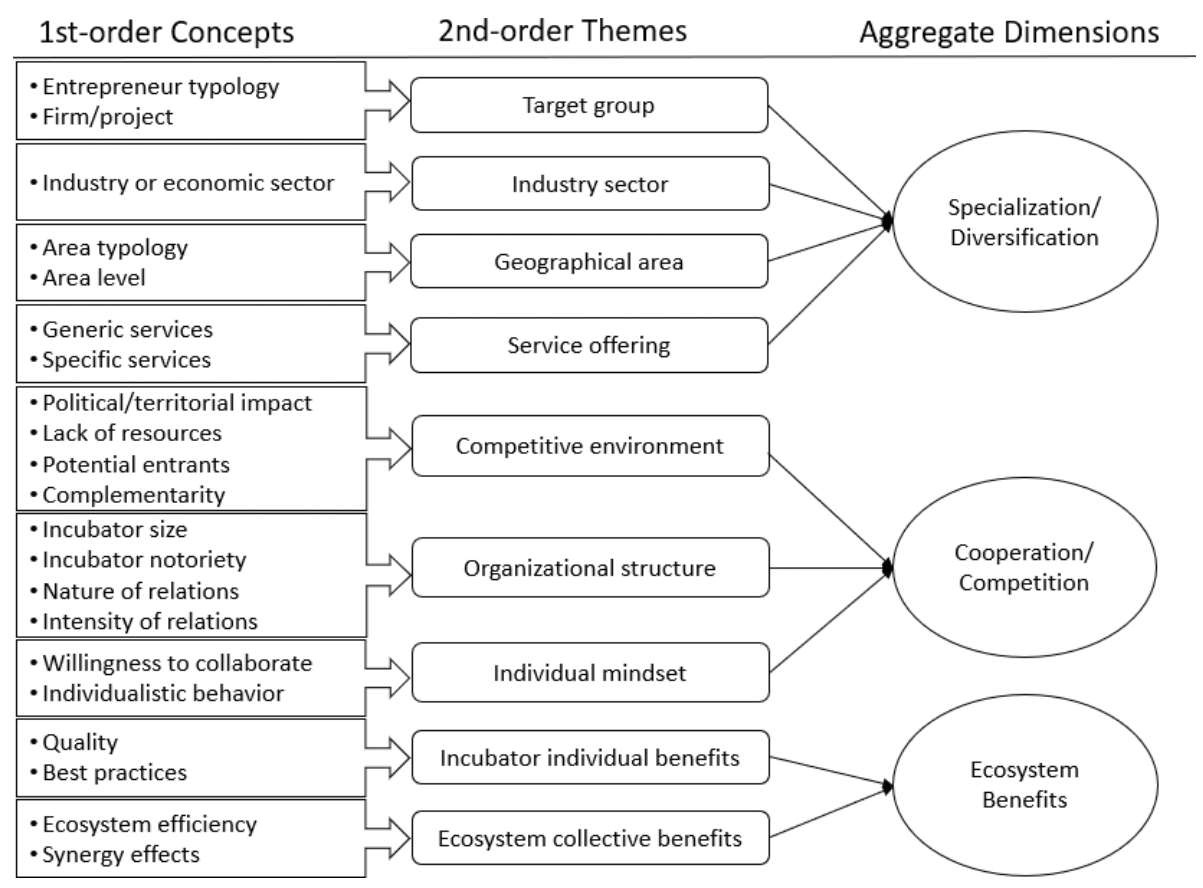

Figure 2. Data structure

\section{Within-case, cross-case, and cross-level findings}

The analysis of the results (see Appendix) intended to facilitate a better understanding of the entrepreneurial support ecosystem and identify the internal and external strategic fit driving incubator differentiation that may lead to better individual and/or collective benefits. This section adopts a crosslevel lens to understand (I) how incubators elaborate internal 
Table 3. Incubators' differentiation criteria by individual strategies

\begin{tabular}{|c|c|c|c|c|c|}
\hline & $\begin{array}{l}\text { Case A: economic } \\
\text { development incubators }\end{array}$ & $\begin{array}{l}\text { Case B: technology } \\
\text { incubators }\end{array}$ & $\begin{array}{l}\text { Case C: university } \\
\text { incubators }\end{array}$ & $\begin{array}{l}\text { Case D: social } \\
\text { incubators }\end{array}$ & Case E: private incubators \\
\hline By target group & $\begin{array}{l}\text { SMEs, micro-projects, } \\
\text { craftsman, unemployed }\end{array}$ & Innovative projects & $\begin{array}{l}\text { Researchers, PhD } \\
\text { students, doctors, } \\
\text { engineers, project } \\
\text { leaders from } \\
\text { laboratories }\end{array}$ & $\begin{array}{l}\text { Natural, legal, or social } \\
\text { entrepreneurs, coopera- } \\
\text { tives, communities, } \\
\text { inter-cities, countries }\end{array}$ & $\begin{array}{l}\text { Natural or legal } \\
\text { entrepreneurs, businesses, } \\
\text { communities, inter-cities, } \\
\text { countries }\end{array}$ \\
\hline By industry sector & $\begin{array}{l}\text { Craftsmanship, specific } \\
\text { sectors (cosmetics, } \\
\text { agronomy, agriculture, } \\
\text { tourism, etc.) }\end{array}$ & $\begin{array}{l}\text { Digital, technology, } \\
\text { health sciences, } \\
\text { engineers }\end{array}$ & $\begin{array}{l}\text { Related to nearby } \\
\text { laboratories (material } \\
\text { sciences, digital, biology, } \\
\text { health, chemistry, etc.) }\end{array}$ & $\begin{array}{l}\text { Social solidarity economy } \\
\text { (handicapped, human } \\
\text { services, health related) }\end{array}$ & $\begin{array}{l}\text { All sectors, public and } \\
\text { private }\end{array}$ \\
\hline \multirow[t]{2}{*}{ By geographical area } & - Rural/urban & - Mainly urban & - Mainly urban & - Mainly urban & - Rural/urban \\
\hline & $\begin{array}{l}\text { - Regional/departmental/ } \\
\text { local }\end{array}$ & $\begin{array}{l}\text { - International/national/ } \\
\text { regional/departmental }\end{array}$ & - National/regional & - National/regional & $\begin{array}{l}\text { - International/national/ } \\
\text { regional/departmental }\end{array}$ \\
\hline By service offering & $\begin{array}{l}\text { A range of generic } \\
\text { services (operational } \\
\text { services, networking, } \\
\text { training) }\end{array}$ & $\begin{array}{l}\text { A range of specific } \\
\text { services (services } \\
\text { related to technology, } \\
\text { networking, training) }\end{array}$ & $\begin{array}{l}\text { A range of specific } \\
\text { services (services } \\
\text { related to technology, } \\
\text { networking) }\end{array}$ & $\begin{array}{l}\text { A range of generic } \\
\text { services (operational } \\
\text { services, networking, } \\
\text { training) }\end{array}$ & $\begin{array}{l}\text { A range of generic and/or } \\
\text { specific services }\end{array}$ \\
\hline
\end{tabular}

and external strategic fit as a differentiation engine and (2) how incubators' differentiation engine contributes to elaborating an ideal strategic fit within the entrepreneurial support ecosystem.

\section{Incubators' differentiation by individual strategies}

Under the theoretical framework presented earlier, the individual differentiation strategies mobilized by incubators consist of specialization or diversification. The main criterion used to distinguish these generic strategies is the choice of centralizing in one or more industry sectors. Thus, the following results reveal the complementary criteria of incubators' differentiation, that is, the target group, industry sector, geographical area, and service offerings (see Table 3).

To minimize the lack of visibility and clarify the role of each actor in the entrepreneurial support ecosystem, different types of incubators may focus on one or more user groups. For example, economic development incubators mainly focus on small and medium-sized enterprises, micro-projects, craftsmen, or people aiming to become employed by starting their own businesses. However, this category is directly related to the choice of industry sector. Furthermore, each type of incubator can be differentiated based on its geographical area at two levels, that is, (I) rural or urban and (2) local, departmental, regional, national, or international. For example, economic development incubators may be found in both rural and urban settings. However, their vocation is often limited to the local or departmental level, and they often have federal representatives at the regional level as is the case with the chambers of commerce. In contrast, technology incubators frequently occur at all geographic levels - even at the international level - and involve and promote high-potential technology-based firms worldwide. The final category of differentiation criteria is service offerings. Each incubator type offers a range of generic or specific services related to the needs of its tenants. These categories can be fulfilled using the temporal criteria of differentiation related to the incubation phase, that is, before or after a firm's creation. Incubators may also differentiate by the duration of the incubation program (see Table I). For example, university incubators are mainly positioned prior to firm creation as they focus on the maturation and incubation of an idea until a firm is created. Therefore, their incubation process is shorter than that typical of economic development incubators (18 months versus 3-5 years, respectively).

Proposition I: The target group, industry sector, geographical area, and service offerings related to the incubator phase and duration contribute to shaping the internal strategic fit differentiation within the entrepreneurial support ecosystem.

\section{Incubators' differentiation by collective strategies}

Collective strategies are framed in the following three categories: competitive environment, organizational structure, and individual mindset. The first category relies on the scalability of incubators' external environment, which imposes a competitive repositioning of actors that ensures their place in the ecosystem, especially as incubators multiply. In the French context, most incubators are closely linked to local policy makers. Consequently, their objectives are frequently related to the goals of the political party that they represent. In parallel, the instability of financial resources increases the competitive spirit among ecosystem actors to acquire or maintain the largest 
piece of the 'cake' and ensure their sustainability. Similarly, competitors and potential new entrants strengthen the competition among ecosystem actors. A network coordinator stated the following: "In fact, the public authorities have created a new support entity that did not exist before, which has created a certain form of competition, and then, there is also competition regarding budgets" (NC\#I). Nonetheless, their complementarity provides a sort of equilibrium that frames the entrepreneurial support ecosystem.

The second category includes incubators' organizational structure. Competition may occur among incubators of the same or similar sizes and is particularly notable among large incubators in their effort to attract high-potential firms. However, small incubators may feel powerless compared to larger incubators and, thus, attempt to minimize the sense of competition among them. "Competition remains for large incubators that have projects with potential. People who develop their project here, they do not care; they just want to develop their project. So, it is not the typology [of tenants] that we have in small incubators. It is less competitive. If we can attract one project like that every two or three years, that is not what is going to put us in competition with them [the large incubators]" (IM\#Case_A\#6). Additionally, incubators are locked in a continuous struggle to improve their notoriety and become more visible than other ecosystem actors. However, incubators frequently co-support tenants to maximize the value added. "We never provide support alone because at this stage, the support, which I would describe as economic, is largely as important as technological support. It is important to have support throughout the business plan, and that is not our job at all. So, we are going to co-support the technological dimension of the project. We will provide insight to the project adviser, who is often a generalist" (IM\#Case_B\#I). Moreover, the lack of resources, skills, time, or staff leads ecosystem actors to collaborate by subcontracting certain services. Ecosystem actors develop formal and informal relationships among themselves to meet the needs of high-potential firms. Thus, frequent meetings and the proximity of actors help develop strong ties among incubators.

The third category frames the level of the individual mindset based on incubator managers' perceptions. Competitive perceptions frequently arise from individualistic behaviors related to decreasing public funding. A network coordinator admits the following: "I am going to try to use a budget that the other one had since money is now scarce" (NC\#I). Similarly, certain actors develop user ownership practices to meet the quantitative criteria imposed by their funders. However, other actors use public funds to offer free services and compete with actors who charge for such services or private incubators. A network coordinator argues that some incubator managers use commercial arguments to attract tenants as follows: "If you come to my incubator, space facilities are free" (NC\#2).
However, even when competitive strategies manifest within the entrepreneurial support ecosystem, actors often simultaneously implement cooperative strategies. Most respondents acknowledge that they are willing to collaborate according to the directives of policy makers who support collaborative approaches among ecosystem actors. A policy maker affirms the following: "I think that incubators are looking for contact. During the plenary sessions of the regional innovation network, we feel that there is a desire and willingness to collaborate, to exchange and share" (INS\#I).

Proposition 2: The competitive environment, organizational structure, and individual mindset contribute to shaping the external strategic fit differentiation within the entrepreneurial support ecosystem.

\section{Cross-level strategic fit differentiation engine model}

\section{Cross-level strategic fit differentiation engine}

The evidence from the cases indicates that the differentiation strategic fit varies based on environmental specificities, incubator types, and individual perceptions (see Figure 3). Regarding environmental specificities, the informants confirmed that policy makers are highly concerned with improving the image of their territory based on rare specialized services and industry focus. "In fact, we are indeed one of the first and one of the few regions to have set up a service dedicated to the social and solidarity economy within its business development department. Additionally, the other innovation is that we are the only region, or at least the first there too, that has set up an incubator" (INS\#I). Furthermore, recent evolutions and trends favor differentiation efforts through the emergence of new niches of specific target groups. "The recent fact is that student entrepreneurship was not given much attention until two years ago. That is really emerging. There is strong motivation, pressure and significant resources allocated at the national level by the state to promote student entrepreneurship in eligible institutions" (IM\#Case_C\#4). Similarly, environmental changes related to potential new entrants, competitors or the evolution of financial resources disrupt the equilibrium and lead to a strategic misfit. "Each regional ecosystem is specific. There may be state-led programs that are well articulated, complete the system and integrate well. On the other hand, the same programs in other regions will make a mess because there are already people who have positioned themselves on this, which puts them in competition. This can destabilize the ecosystem, that is for sure" (IM\#Case_B\#I).

Strategic fit is also related to organizational characteristics based on the target of companies or the focus on specific industries aiming to provide local economic development 


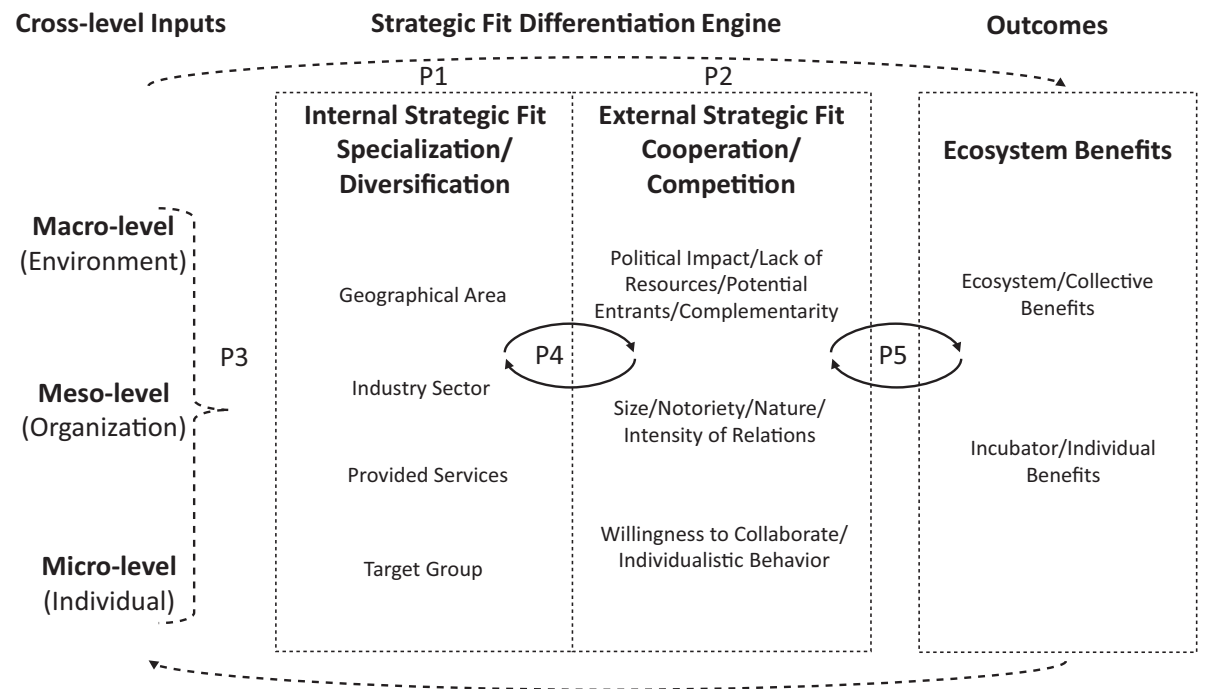

Figure 3. Cross-level strategic fit differentiation engine model

through innovation and employment. "We are an incubator for innovative companies through several support processes that range from project incubation in a pre-incubator to hosting a company in the incubator and now accelerating mature companies in an accelerator. The whole strategy of our incubator is to develop the territory through innovation" (IM\#Case_A\#5). In addition, some incubators face competition by users, which is particularly related to their specific group target of high-potential firms. Such entrepreneurs know their abilities and do not hesitate to meet various incubators to rank the value added by each of their proposals. This behavior is reinforced because most incubators prefer to attract such tenants to improve their notoriety. "Several times, we had project leaders that were in contact with us and had also met several other incubators. Then, they had to choose one of these incubators. So, they [the incubators] were in fact in competition with each other.They all tried to attract them" (IS\#Case_C\#I). However, in most cases, individuals appreciate cooperation due to their common values. "I think it really depends on the individuals. Martin [IM\#Case_A\# II, rural incubator] is a lovely person, and he is honest too; if we have to say something to each other, we are going to say it. We avoid being in unhealthy competition" (IM\#Case_A\#6, rural incubator).

Proposition 3: The environmental specificities, organization characteristics, and individual perceptions contribute to shaping the ideal strategic fit within the entrepreneurial support ecosystem.

\section{Strategic fit differentiation engine interactions}

The internal and external strategic fit are interconnected and interdependent in shaping the incubator strategic positioning in the entrepreneurial support ecosystem. Key informants stated that the target or industry focus, service offerings, and focus on a geographical area may influence co-opetition. An incubator staff member testified the following: "It is the same job, but after that, we all have our specificities. Here, we only support projects related to a lab" (IS\#Case_C\#I). However, cross-level competition could be fostered by the evolution of the ecosystem. An incubator manager confirmed the following: "Competition is enhanced from two things: territories and proximity - being next door and doing the same thing. The less we do the same thing, the less we are in competition. Typically, if tomorrow there is another incubator that opens but will provide support for a market segment or a sector of activity in which we are not involved, then it is not going to be a problem for us as we will not be competitors at all. On the other hand, we do cosmetics. If an incubator that provides support for cosmetics opens tomorrow, then yes, we will indeed be competitors" (IS_Case_A\#9). Thus, increasing specialization decreases competition in a healthy ecosystem with low individualistic behaviors. "If I am a social economy incubator, I will attract projects that are in the social and solidarity economy. If I am an art-specialist incubator, I will attract projects that are specialized in art. If I am a sport-specialist incubator, I will attract projects that are specialized in tourism or sports. There is competition, yes, but there are also sometimes niches" (RE\#2).

In contrast, outsourcing activities foster cooperation among ecosystem actors who offer services when incubators cannot provide such services alone. "There are a lot of services that we provide that are outsourced. I told you about the hosting. We do not have offices to accommodate project leaders; in fact, they are hosted within research organizations or universities that have set up offices or workshops for incubated 
projects because they are members of our association and have, therefore, made the decision to set up a hosting offer" (IS\#Case_C\#I).

Proposition 4: The internal and external strategic fit contribute to shaping the ideal strategic fit within the entrepreneurial support ecosystem.

\section{The strategic fit differentiation engine's outcomes}

Our findings highlight that the strategic fit differentiation engine influences individual and collective benefits. Ecosystem commitment is necessary for providing high-quality services and preserving the incubator image. An incubator staff member explains the following: "I think that we cannot live separately from the network. Well, we can; it is not vital, but the support will not be of good quality" (IS\#Case_A\#9). This ecosystem perspective acts as a stimulator for improvement. An incubator staff member claims the following: "When you have incubators that work faster than you that develop better, you also tend to move. These market principles with several players and competition ultimately lead to improvement in proposals in terms of offers" (IS\#Case_A\#I). Similarly, complementarity and synergy are key to the success of the ecosystem by increasing the ecosystem's efficiency. An incubator staff member considered the following: "When you have better relationships with your ecosystem, you are necessarily more efficient" (IS\#Case_A\#7).

To achieve efficiency, individual and collective interests must be balanced by intelligent cooperation among ecosystem actors. "Of course, we have our own service offer, but we also developed our ability to work in good understanding with everyone without promoting individual development" (IM\#Case_B\#I). "There is still a real collaborative intelligence. In other words, I think that there must indeed be some form of competition and a willingness to do better than the other, but not in the sense of putting obstacles in the way. I think that there is this intelligence that we are all working in the same direction" (IM\#Case_E\#2).

In addition, the lack of resources, organization disparities, and incubator manager perceptions amplify the interdependencies of individual and collective benefits. "I cannot perform on my own. I am very intelligent and efficient, yes, but not for all companies, all situations, or all sectors of activity; it is not possible. We have to be in a network and be in contact with each other because otherwise, it will not work" (IM\#Case_A\#6). Thus, to maintain the benefits, actors must efficiently live together, and ecosystem actors must respect and serve the same goal. "This is a very healthy competition. Today, incubators manage to live together and collaborate because we know each other anyway, and we are following the same qualitative logic. We are not following a quantitative logic where we force people to create their own businesses to get results by saying that we have so many new businesses. Our objective is to maintain quality and to ensure that the actors work in this relationship and respect this objective" (IS\#Case_A\#I).

Proposition 5: An ideal strategic fit differentiation engine driven by environmental, organizational, and individual specificities contributes to enhance both incubator and ecosystem benefits within the entrepreneurial support ecosystem, which, in turn, contribute to evolve the strategic fit differentiation engine.

\section{Discussion and conclusion}

\section{Differentiation strategies within the entrepreneurial support ecosystem}

Previous studies show that incubators differentiate through internal strategic fit using specialization or diversification strategies (Schwartz \& Hornych, 2008, 2010, 2012; Vanderstraeten \& Matthyssens, 20 I2). However, internal fit is not sufficient for selecting the ideal incubator strategy, which should instead be adjusted based on environmental and cultural features (Adner, 2017; Schwartz \& Hornych, 2012 ; Spigel, 2017 ; Theodoraki, Messeghem, \& Rice, 2018 ; Vanderstraeten \& Matthyssens, 20I2). Similarly, ecosystem actors should find a balance between serving an entrepreneurial goal and seeking competitive advantages (Shankar \& Shepherd, 2019). Overall, the results suggest that differentiation is reinforced by (I) environmental factors as public funding decreases and the competitive market becomes more intense with the multiplication of the number of actors, (2) organizational factors based on incubator notoriety and ecosystem actors' relationship management, and (3) individual factors related to co-opetition behaviors.

An analysis of the entrepreneurial support ecosystem shows that many actors compete by operating with a market logic to attract their customers. Moreover, changes in the economic environment, both institutional and regulatory, affect co-opetitive behaviors (Padula \& Dagnino, 2007). Indeed, in times of crisis or periods characterized by intense economic rivalry, incubators may move away from their main goals to survive. In addition, the increasing number of actors and the lack of clarity regarding strategic objectives and tasks can lead to indistinct offers of support and increased competition among actors. Another element enhancing competition among actors in terms of entrepreneurial support involves the decreasing financial resources that the actors must share. The International Business Innovation Association ( $\ln B \mid A)$ reports that incubators compete for limited public funds and must regularly demonstrate that their existence significantly affects the entrepreneurial support ecosystem to their funders and governments (Lair, 2013). To gain a 
competitive advantage over other actors, incubators highlight their seniority and experience (historical legitimacy), their mission and the value added for tenants (organizational legitimacy), and their fame and reputation (symbolic legitimacy).

Finally, the findings propose a cross-level differentiation model for shaping ideal strategies and suggest that each type of incubator should employ different combinations of internal and external strategic fit based on incubator's organizational characteristics, its manager's perceptions, and environmental specificities. For example, a rural economic development incubator may establish a diversification strategy with a focus on cooperation as the talent pool is limited, while a technology incubator may promote a specialization strategy with a focus on competition to attract high potential firms that will increase incubator's performance. Therefore, incubators' equifinality allows the selection of different strategies to gain benefits and create additional value in the entrepreneurial support ecosystem (Doty et al., 1993; Jacobides et al., 2018). Thus, seemingly important directions for future research are the identification of ideal strategies to increase performance based on each ecosystem actor's strategic focus (Vanderstraeten \& Matthyssens, 2012) and the creative business model thinking, which shows several paths that can lead to superior performance (Demil et al., 20 18).

\section{Implications and contributions}

This research introduces a co-opetition strategy to the entrepreneurial support field and provides a holistic view of incubators' differentiation within the entrepreneurial support ecosystem (Schwartz \& Hornych, 2012; Vanderstraeten \& Matthyssens, 2012). Basically, this study responds to the research gaps identified by incubator strategy scholars and considers incubators' environmental characteristics (Baraldi \& Havenvid, 2016; Schwartz \& Hornych, 2008, 2010, 2012; Vanderstraeten \& Matthyssens, 2012). This paper also contributes to theory regarding co-opetition by integrating co-opetition into the context of incubators and adding empirical work in other contexts as recommended in the previous literature (Bonel \& Rocco, 2007; Dagnino et al., 2007; Gnyawali \& Charleton, 2018; Padula \& Dagnino, 2007; Yami et al., 20 I0). Thus, this study sheds light on co-opetition mechanisms that may lead to beneficial outcomes (Gnyawali \& Charleton, 20 I8). The present paper provides empirical evidence for ecosystem theory in the context of incubators by conducting a meso-level analysis (incubators and other ecosystem actors), which exceeds the intra-incubator level (cooperation and competition between tenants) (Clarysse et al., 2014; Rubin et al., 2015; Schwartz \& Hornych, 2010). Additionally, this study adopts an ecosystem approach that crosses the visions of the main actors involved in the entrepreneurial support ecosystem (Ben Letaifa, 2013).

This study also presents managerial implications for all ecosystem actors by providing important insight into incubators. Specifically, incubators should implement strategies as integral part of the ecosystem rather than as singular independent strategically led organizations. For this purpose, the cross-level strategic fit differentiation engine model may be used as a tool to guide ideal strategic fit elaboration and implementation, specifically for incubator managers and policy makers. Incubator managers may use the ecosystem to represent their environment and adopt appropriate generic strategies that can enable them to gain a competitive advantage and improve their efficiency. Policy makers can encourage incubators to engage in co-opetitive strategies to optimize resources and reduce duplication among actors, thereby reinforcing the consistency of entrepreneurial support channels. Furthermore, hybrid strategies, such as co-opetition, may increase individual and collective benefits while strengthening local economic development. Finally, this cross-level strategic fit differentiation engine model offers a multi-dimensional perspective and can be used as a communication tool among incubator managers, policy makers, and other ecosystem actors to collectively engage in a coherent territorial strategy.

\section{Research limitations and future perspectives}

Despite the interests of this study, certain limitations mainly involving the qualitative methodology used must be addressed. This study focuses on a single French region, indicating that the generalizability of these results is limited. Additionally, this study is based on a small number of interviews per incubator type. Another limitation may be the typologies of the studied incubators. This study selected five types of incubators based on their strategic focuses. Thus, other typologies based on the incubation phase, that is, preincubation, incubation, and acceleration, may be interesting to investigate in future research. This process-based approach applied to incubators' strategic fit differentiation could foster a deeper understanding of the entrepreneurial support ecosystem, its evolution, and its resilience (Bernard \& Barbosa, 2016; Goswami et al., 2018; Roundy et al., 2017; Shankar \& Shepherd, 2019; Spigel \& Harrison, 2018). Methodology recommendations include comparative studies in other regions to confirm or amend the present findings. Further investigation is required to examine the congruence between internal and external fit and incubator performance. Accordingly, future studies may explore which combination of individual (specialization or diversification) and/or collective (co-opetition) strategies facilitate superior performance. Some authors contend that specialization may lead to better performance (Kapoor, 2013; Schwartz \& Hornych, 2008), whereas other scholars consider 
that a combination of strategies should be consistent with the external environment (Bank et al., 2017; McAdam et al., 20 I6; Schwartz \& Hornych, 2012) and the organization's business model (Demil et al., 20।8). Performing a quantitative study of incubator strategies is also important to test these preliminary results on a larger scale. While encouraged by this study's findings, which consider incubators (I) as strategically led organizations, (2) operating in interaction with ecosystem actors and (3) implementing strategies within the entrepreneurial support ecosystem, such research has not been performed to date and could offer new perspectives for entrepreneurial ecosystems research.

\section{Acknowledgments}

I am grateful to the participants of the special SMS Conference on the Entrepreneurial Ecosystems in Rome, Italy on June 5-7, 2016, the Entrepreneurial Ecosystem Symposium in Adelaide, Australia on June 14-15, 2016, and the AOM Annual Conference in Anaheim, USA on August 5-9, 2016 for their inspiring feedback. I appreciate the suggestions from Professors Karim Messeghem, David B. Audretsch, and from the TBS Research Laboratory of Entrepreneurship and Strategy.

\section{Funding}

This study is funded by LabEx Entreprendre: government-funded through the National Research Agency as part of the 'Invest in the Future' program; reference: ANR- I0-LABX-||-0|.

\section{References}

Adner, R. (2017). Ecosystem as structure: An actionable construct for strategy.journal of Management,43( I),39-58.doi: I 0. I I77/0 I 492063 I 667845 I

Aernoudt, R. (2004). Incubators: Tool for entrepreneurship? Small Business Economics, 23(2), I27-I35. doi: I0. I023/B:SBEJ.0000027665.54I73.23

Aerts, K., Matthyssens, P. \& Vandenbempt, K. (2007). Critical role and screening practices of European business incubators. Technovation, 27(5), 254-267. doi: I0. 101 6/j.technovation.2006. 12.002

Aguinis, H. \& Solarino, A. M. (2019). Transparency and replicability in qualitative research: The case of interviews with elite informants. Strategic Management Journal, 40(8), |29|-1315. doi: 10.1002/smj.3015

Akdoğan, A. A. \& Cingšz, A. (2012). An empirical study on determining the attitudes of small and medium sized businesses (SMEs) related to coopetition. Procedia - Social and Behavioral Sciences, 58, 252-258. doi: I0. I 0 | 6/j.sbspro.2012.09.999

Al-Mubaraki, H. M. \& Busler, M. (20 I0). Business incubators: Findings from a worldwide survey, and guidance for the GCC states. Global Business Review, I I ( I), I-20. doi: I0.1 I77/0972 I509090 I I00 I 0 I

Bank, N., Fichter, K. \& Klofsten, M. (2017). Sustainability-profiled incubators and securing the inflow of tenants - The case of Green Garage Berlin. Journal of Cleaner Production, 157, 76-83. doi: 10.1016/j. jclepro.2017.04.123
Bansal, P. \& Corley, K. (20I2). Publishing in AMJ - Part 7: What's different about qualitative research? Academy of Management Journal, 55(3), 509-5 | 3. doi: I0.5465/amj.20 I2.4003

Baraldi, E. \& Havenvid, M. I. (2016). Identifying new dimensions of business incubation: A multi-level analysis of Karolinska Institute's incubation system. Technovation, 50-51, 53-68. doi: 10.1016/j. technovation.2015.08.003

Barbero, J. L., Casillas, J. C., Ramos, A. \& Guitar, S. (20/2). Revisiting incubation performance: How incubator typology affects results. Technological Forecasting and Social Change, 79(5), 888-902. doi: 10.1016/j. techfore.20I I. I2.003

Bazeley, P. \& Jackson, K. (20 I 3). Qualitative data analysis with in vivo. Sage.

Ben Letaifa, S. (20 I 3). A methodology for ecosystem creation: How organizations can shift from supply chain to ecosystems. In S. B. Letaifa, A. Gratacap \& T. Isckia (Eds.), Understanding business ecosystems: How firms succeed in the new world of convergence? (pp. 86-95). De Boeck.

Ben Letaifa, S. \& Rabeau,Y. (20 I 3). Too close to collaborate? How geographic proximity could impede entrepreneurship and innovation. Journal of Business Research, 66( I0), 207 I-2078. doi: I 0. I 0 | 6/j.jbusres.20 I3.02.033

Bengtsson, M., Eriksson, J. \& Wincent, J. (2010). Co-opetition dynamics - An outline for further inquiry. Competitiveness Review, 20(2), 194-214. doi: I0.1 I08/I059542 I 011029893

Bengtsson, M. \& Johansson, M. (20।4). Managing coopetition to create opportunities for small firms. International Small Business Journal, 32(4), 40 I-427. doi: I0. I 177/02662426/246/288

Bengtsson, M. \& Kock, S. (1999). Cooperation and competition in relationships between competitors in business networks. Journal of Business \& Industrial Marketing, I 4(3), I78-194. doi: I 1. I 108/088586299 I 0272 I 84

Bengtsson, M. \& Kock, S. (2000). 'Coopetition' in business networks - To cooperate and compete simultaneously. Industrial Marketing Management, 29(5), 4 I I-426. doi: I 0. I 1 I 6/500 I 9-850 I (99)00067-X

Bergek, A. \& Norrman, C. (2008). Incubator best practice: A framework. Technovation, 28(I-2), 20-28. doi: I 0. I I 6/j.technovation.2007.07.008

Bernard, M. J. \& Barbosa, S. D. (20|6). Resilience and entrepreneurship: A dynamic and biographical approach to the entrepreneurial act. M@n@ gement, 19(2), 89-123. doi: 10.39/7/mana. 192.0089

Bøllingtoft, A. (2012). The bottom-up business incubator: Leverage to networking and cooperation practices in a self-generated, entrepreneurial-enabled environment. Technovation, 32(5), 304-315. doi: I0. I I 6/j. technovation.2011.11.005

Bøllingtoft, A. \& Ulhøi, J. P. (2005). The networked business incubator Leveraging entrepreneurial agency? Journal of Business Venturing, 20(2), 265-290. doi: I0. I 0 I 6/j.jbusvent.2003. 12.005

Bonel, E., Pellizzari, P. \& Rocco, E. (2008). Coopetition and complementarities: Modeling coopetition strategy and its risks at an individual partner level. Management Research, 6(3), I89-205. doi: 10.2753/ JMRI536-5433060303

Bonel, E. \& Rocco, E. (2007). Coopeting to survive; surviving coopetition. International Studies of Management \& Organization, 37(2), 70-96. doi: 10.2753/IMO0020-8825370204

Brandenburger, A. M. \& Nalebuff, B. J. (1995). The right game: Use game theory to shape strategy. Harvard Business Review, 73(4), 57-71. doi: I O. I OI 6/0024-630 I (95)90326-7

Brown, R. \& Mason, C. (2017). Looking inside the spiky bits: A critical review and conceptualisation of entrepreneurial ecosystems. Small Business Economics, 49( I), I |-30. doi: | 0.1007/s | | | 87-0 | 7-9865-7

Carayannis, E. G. \& Alexander, J. (1999). Winning by co-operating in strategic government-university-industry R\&D partnerships: The power of complex, dynamic knowledge networks. The Journal of Technology Transfer, 24(2/3), 197-2 10. doi: I0.1023/A: 1007855422405 
Carayannis, E. G. \& von Zedtwitz, M. (2005). Architecting gloCal (globallocal), real-virtual incubator networks (G-RVINs) as catalysts and accelerators of entrepreneurship in transitioning and developing economies: Lessons learned and best practices from current development and business incubation practices. Technovation, 25(2), 95-110. doi: 10.1016/ Sol 66-4972(03)00072-5

Chan, K. F. \& Lau,T. (2005). Assessing technology incubator programs in the science park: The good, the bad and the ugly. Technovation, 25(10), 1215-1228. doi: 10.1016/j.technovation.2004.03.010

Chandra, A. \& Fealey, T. (2009). Business incubation in the United States, China and Brazil: A comparison of role of government, incubator funding and financial services. International Journal of Entrepreneurship, 13, 67-86.

Chetty, S. K., Partanen, J., Rasmussen, E. S. \& Servais, P. (20।4). Contextualising case studies in entrepreneurship: A tandem approach to conducting a longitudinal cross-country case study. International Small Business Journal, 32(7), 818-829. doi: | 0.1 177/02662426|247| 962

Chiambaretto, P. \& Dumez, H. (2016). Toward a typology of coopetition: A multilevel approach. International Studies of Management \& Organization, 46(2-3), I I0-129. doi: I 0.1080/00208825.20 15. 1093797

Clarysse, B., Wright, M., Bruneel, J. \& Mahajan, A. (20 I 4). Creating value in ecosystems: Crossing the chasm between knowledge and business ecosystems. Research Policy, 43(7), I | 64- | | 76. doi: | 0. I 0 | 6/j.respol.20 I 4.04.0 I 4

Clarysse, B., Wright, M., Lockett, A., Van de Velde, E., et al. (2005). Spinning out new ventures: A typology of incubation strategies from European research institutions. Journal of Business Venturing, 20(2), 183-216. doi: I0.1 0 | 6/j.jbusvent.2003. 12.004

Cohen, B. (2006). Sustainable valley entrepreneurial ecosystems. Business Strategy and the Environment, 15(I), I-14. doi: 10.1002/bse.428

Corley, K. G. \& Gioia, D. A. (2004). Identity ambiguity and change in the wake of a corporate spin-off. Administrative Science Quarterly, 49(2), |73-208. doi: |0.2307/4|3|47|

Dagnino, G. B., Le Roy, F. \& Yami, S. (2007). La dynamique des stratégies de coopétition. Revue Française de Gestion, 33(176), 87-98. doi: I0.3166/ rfg. $176.87-98$

Demil, B., Lecocq, X. \& Warnier, V. (20।8). 'Business model thinking', business ecosystems and platforms: The new perspective on the environment of the organization.M@n@gement,2 I (4), I213-1228.doi: 10.39 I7/mana.214.1213

Doty, D. H., Glick, W. H. \& Huber, G. P. (1993). Fit, equifinality, and organizational effectiveness: A test of two configurational theories. Academy of Management Journal, 36(6), I | 96-1250. doi: I0.5465/2568 I0

Drazin, R. \& Van deVen, A. H. (1985). Alternative forms of fit in contingency theory. Administrative Science Quarterly, 30(4), 5 I4-539. doi: I0.2307/ 2392695

Eisenhardt, K. M. \& Graebner, M. E. (2007). Theory building from cases: Opportunities and challenges. Academy of Management Journal, 50(I), 25-32. doi: I 0.5465/amj.2007.24|60888

Etzkowitz, H., de Mello, J. M. C. \& Almeida, M. (2005).Towards 'meta-innovation' in Brazil:The evolution of the incubator and the emergence of a triple helix. Research Policy, 34(4), 4 I I-424. doi: I 0. I 0 I 6/j.respol.2005.0 I.0 I I

Gibbert, M., Ruigrok, W. \& Wicki, B. (2008). What passes as a rigorous case study? Strategic Management Journal, 29( I 3), | 465-| 474. doi: I0. I002/ smj.722

Ginsberg, A., Horwitch, M., Mahapatra, S. \& Singh, C. (20I0, July). Ecosystem strategies for complex technological innovation: The case of smart grid development. PICMET 2010 Technology Management for Global Economic Growth Proceedings, Phuket, Thailand, I-8. https://ieeexplore.ieee.org/ document $/ 5603368$

Ginsberg, A. \& Venkatraman, N. (1985). Contingency perspectives of organizational strategy: A critical review of the empirical research. Academy of Management Review, 10(3), 42 I-434. doi: I0.5465/amr. 1985.4278950
Gioia, D. A., Corley, K. G. \& Hamilton, A. L. (20 I 3). Seeking qualitative rigor in inductive research. Organizational Research Methods, I6(I), |5-31. doi: | 0.1 | 177/ |094428| | 2452/5 |

Gnyawali, D. R. \& Charleton, T. R. (2018). Nuances in the interplay of competition and cooperation: Towards a theory of coopetition. Journal of Management, 44(7), 25 | |-2534. doi: I 0.1 I 77/0 | 492063 | 8788945

Gnyawali, D. R., Madhavan, R., He, J. \& Bengtsson, M. (2016). The competition-cooperation paradox in inter-firm relationships: A conceptual framework. Industrial Marketing Management, 53, 7-18. doi: 10.1016/j. indmarman.2015.1 I.014

Goswami, K., Mitchell, J. R. \& Bhagavatula, S. (20 I8). Accelerator expertise: Understanding the intermediary role of accelerators in the development of the Bangalore entrepreneurial ecosystem. Strategic Entrepreneurship Journal, 12(1), I 17-150. doi: 10.1002/sej. I28 I

Gresov, C. \& Drazin, R. (1997). Equifinality: Functional equivalence in organization design. Academy of Management Review, 22(2), 403-428. doi: | 0.5465/amr. | 997.9707| 54064

Grimaldi, R. \& Grandi, A. (2005). Business incubators and new venture creation: An assessment of incubating models. Technovation, 25(2), I I I| 2 | . doi: | 0. I 0 | 6/S0 | 66-4972(03)00076-2

Huang, H.-C. \& Chu, W. (20I5). Antecedents and consequences of co-opetition strategies in small and medium-sized accounting agencies. Journal of Management \& Organization, 2 I (6), 8| 2-834. doi: | 0.10 | 7/jmo.20 | 4.82

Jacobides, M. G., Cennamo, C. \& Gawer, A. (2018). Towards a theory of ecosystems. Strategic Management Journal, 39(8), 2255-2276. doi: I0. I002/ smj.2904

Kapoor, R. (2013). Persistence of integration in the face of specialization: How firms navigated the winds of disintegration and shaped the architecture of the semiconductor industry. Organization Science, 24(4), | | 95-|2 | 3. doi: | 0. I 287/orsc. I | 20.0802

Kim, M.-J., Lee, J. \& Park, J.-Y. (20I5). The effect of cooperation-strategy fit on the performance of subcontractors-focused on Samsung electronics' subcontractors. Journal of Economics, Business and Management, 3(3), 370-376. doi: I0.7763/JOEBM.20I5.V3.212

Klofsten, M., Lundmark, E., Wennberg, K. \& Bank, N. (2020). Incubator specialization and size: Divergent paths towards operational scale. Technological Forecasting and Social Change, 151, I 19821. doi: 10.1016/j. techfore.2019.119821

Kœnig, G. (2012). Business ecosystems revisited. M@n@gement, 15(2), 208-224. doi: $10.3917 /$ mana. 152.0209

Lair, B. (2013). Incubating in rural areas: Successful programs in small communities. InBIA Review, 29(I), I-16.

Mariani, M. M. (2016). Coordination in inter-network co-opetitition: Evidence from the tourism sector. Industrial Marketing Management, 53, I03-123. doi: 10.1016/j.indmarman.2015.1 I.015

Mason, C. \& Brown, R. (20I4). Entrepreneurial ecosystems and growth-oriented entrepreneurship. OECD report. https://www.oecd.org/cfe/leed/ entrepreneurial-ecosystems.pdf

McAdam, M. \& Marlow, S. (2008). A preliminary investigation into networking activities within the university incubator. International Journal of Entrepreneurial Behavior \& Research, I 4(4), 2 19-24I. doi: I0.1 I 08/ I35525508 I 0887390

McAdam, M., Miller, K. \& McAdam, R. (2016). Situated regional university incubation: A multi-level stakeholder perspective. Technovation, 50-51, 69-78. doi: 10.10 16/j.technovation.2015.09.002

Messeghem, K., Bakkali, C., Sammut, S. \& Swalhi, A. (20 I 8). Measuring nonprofit incubator performance: Toward an adapted balanced scorecard approach. Journal of Small Business Management, 56(4), 658-680. doi: 10.1 | | |/jsbm. 12317

Miller, D. (1992). Environmental fit versus internal fit. Organization Science, 3(2), I59-178. doi: 10.1287/orsc.3.2. 159 
Minà, A., Dagnino, G. B. \& Ben Letaifa, S. (20 I5). Competition and cooperation in entrepreneurial ecosystems: A life-cycle analysis of a Canadian ICT ecosystem. In F. Belussi \& L. Orsi (Eds.), Innovation, alliances, and networks in high-tech environments (pp. 65-8I). Routledge.

Morris, M. H., Neumeyer, X. \& Kuratko, D. F. (20I5). A portfolio perspective on entrepreneurship and economic development. Small Business Economics, 45(4), 7| 3-728. doi: | 0. I007/s | | |87-0| 5-9678-5

Padula, G. \& Dagnino, G. B. (2007). Untangling the rise of co-opetition:The intrusion of competition in a cooperative game structure. International Studies of Management \& Organization, 37(2), 32-52. doi: 10.2753/ IMO0020-8825370202

Pauwels, C., Clarysse, B., Wright, M. \& Van Hove, J. (2016). Understanding a new generation incubation model: The accelerator. Technovation, 50, |3-24. doi: | 0.10 | 6/j.technovation.2015.09.003

Payne, G. T. (2006). Examining configurations and firm performance in a suboptimal equifinality context. Organization Science, 17(6), 756-770. doi: 10.1287/orsc. 1060.0203

Payne, G. T., Kennedy, K. H. \& Davis, J. L. (2009). Competitive dynamics among service SMEs. Journal of Small Business Management, 47(4), 42 I442. doi: 10.1 I | //j. 1540-627X.2009.00277.x

Pena, I. (2004). Business incubation centers and new firm growth in the Basque country. Small Business Economics, 22(3/4), 223-236. doi: 10.102 3/B:SBEJ.0000022221.03667.82

Ritala, P., Hallikas, J. \& Sissonen, H. (2008). Coopetitive networks in the ICT sector. International Journal of Business Environment, 2(1), I-16. doi: I0.1504/JIBE.2008.016838

Robert, M., Chiambaretto, P., Mira, B. \& Le Roy, F. (20l8). Better, faster, stronger, the impact of market oriented coopetition on product commercial performance. M@n@gement, 21 ( ), 574-610. doi: I0.3917/ mana.2 11.0574

Roundy, P.T., Brockman, B. K. \& Bradshaw, M. (2017). The resilience of entrepreneurial ecosystems. Journal of Business Venturing Insights, 8, 99-104. doi: 10.101 6/j.jbvi.2017.08.002

Rubin, T. H., Aas, T. H. \& Stead, A. (20I5). Knowledge flow in technological business incubators: Evidence from Australia and Israel. Technovation, 4I-42, I I-24. doi: 10. I 0 I6/j.technovation.2015.03.002

Schwartz, M. \& Hornych, C. (2008). Specialization as strategy for business incubators: An assessment of the Central German Multimedia Center. Technovation, 28(7), 436-449. doi: I 1 I 10 | 6/j.technovation.2008.02.003

Schwartz, M. \& Hornych, C. (20I0). Cooperation patterns of incubator firms and the impact of incubator specialization: Empirical evidence from Germany. Technovation, 30(9-10), 485-495. doi: 10.1016/j. technovation.2010.05.00।

Schwartz, M. \& Hornych, C. (2012). Specialisation versus diversification: Perceived benefits of different business incubation models. International Journal of Entrepreneurship and Innovation Management, 15(3), 177-197. doi: I 0. I 504/IJEIM.20 I 2.046599

Shankar, R. K. \& Shepherd, D. A. (2019). Accelerating strategic fit or venture emergence: Different paths adopted by corporate accelerators. Journal of Business Venturing, 34(5), 105886. doi: 10.1016/j. jbusvent.2018.06.004

Short, J. C., Payne, G.T. \& Ketchen, D. J. (2008). Research on organizational configurations: Past accomplishments and future challenges. Journal of Management, 34(6), I 053-1079. doi: I 0.1 I 77/0 I 49206308324324
Somsuk, N. \& Laosirihongthong, T. (2014). A fuzzy AHP to prioritize enabling factors for strategic management of university business incubators: Resource-based view. Technological Forecasting and Social Change, 85, 198-210. doi: I0.1016/j.techfore.2013.08.007

Spigel, B. (2017). The relational organization of entrepreneurial ecosystems. Entrepreneurship Theory and Practice, 4I ( I), 49-72. doi: I 0.1 I I I/etap. 12167

Spigel, B. \& Harrison, R. (20।8). Toward a process theory of entrepreneurial ecosystems. Strategic Entrepreneurship Journal, I2(I), |5|-|68. doi: $10.1002 /$ sej. 1268

Stangler, D. \& Bell-Masterson, J. (20।5, March). Measuring an entrepreneurial ecosystem. Ewing Marion Kauffman Foundation. https://www.kauffman. org/wp-content/uploads/2020/05/Measuring-an-EntrepreneurialEcosystem.pdf

Tamasy, C. (2007). Rethinking technology-oriented business incubators: Developing a robust policy instrument for entrepreneurship, innovation, and regional development? Growth and Change, 38(3), 460-473. doi: | 0.1 | | | /j. | 468-2257.2007.00379.x

Theodoraki, C. \& Messeghem, K. (2017). Exploring the entrepreneurial ecosystem in the field of entrepreneurial support: A multi-level approach. International Journal of Entrepreneurship and Small Business, 3/ (I), 47-66. doi: I 0. I504/IJESB.20 I7.083847

Theodoraki, C., Messeghem, K. \& Rice, M. P. (20।8). A social capital approach to the development of sustainable entrepreneurial ecosystems: An explorative study. Small Business Economics, 5I(I), 153-170. doi: | 0.1007/s | | |87-017-9924-0

Thomas, L. D. W. \& Autio, E. (2014). The fifth facet: The ecosystem as an organizational field. Druid Society Conference, Copenhagen. https://pdfs. semanticscholar.org/384e/c63da8667b079dbd04eb3ed460 I bcc959 eeb.pdf

Van de Ven, A. H. \& Drazin, R. (1984). The concept of fit in contingency theory. DTIC Document. https:/apps.dtic.mil/dtic/tr/fulltext/u2/al52603.pdf

van Weele, M., van Rijnsoever, F. J., Eveleens, C. P., Steinz, H. et al. (20l8). Start-EU-up! Lessons from international incubation practices to address the challenges faced by Western European start-ups. The Journal of Technology Transfer, 43(5), | | 6 | - | | 89. doi: | 0. I 007/s | 096 |-0 | 6-9538-8

Vanderstraeten, J. \& Matthyssens, P. (20I2). Service-based differentiation strategies for business incubators: Exploring external and internal alignment. Technovation, 32( I2), 656-670. doi: I0. I 1 | 6/j.technovation.20 I2.09.002

Venkatraman, N. \& Camillus, J. C. (1984). Exploring the concept of 'fit' in strategic management. Academy of Management Review, 9(3), 5 I 3-525. doi: I0.5465/amr. 1984.4279696

von Zedtwitz, M. \& Grimaldi, R. (2006). Are service profiles incubator-specific? Results from an empirical investigation in Italy. The Journal of Technology Transfer, 3 I (4), 459-468. doi: I0. I 007/s I 096 I-006-0007-7

Yami, S., Castaldo, S., Dagnino, B. \& Roy, F. L. (20 I0). Coopetition: Winning strategies for the 2 Ist century. Edward Elgar Publishing.

Yami, S., Chappert, H. \& Mione, A. (20 I5). Strategic relational sequences: Microsoft's coopetitive game in the OOXML standardization process. M@n@gement, 18(5), 330-356. doi: 10.3917/mana. 185.0330

Yin, R. K. (20|8). Case study research: Design and methods. Sage.

\section{Appendix}

